\title{
Determinants of the Components of IPO Initial Returns: Paris Stock Exchange
}

\author{
Adel Boubaker \\ Finance Professor, Faculty of Science Economics and Management of Tunis \\ Campus Universitaire, Ennasr 2, Ariana 2037 Tunisia, +21698430378 (Phone) \\ adel.boubaker@fsegt.rnu.tn \\ Mediha Mezhoud (Corresponding Author) \\ $\mathrm{Ph} \mathrm{D}$ Student, Faculty of Science Economics and Management of Tunis \\ mezhoud.madi7a@gmail.com
}

Received: July 14, 2011 Accepted: September 15, $2011 \quad$ DOI: 10.5296/ijafr.v1i1.986

\begin{abstract}
This study examines a sample of 143 French companies placed on the stock market over the period 2006-2010. Our cross-sectional analysis shows that it is essential to separate the initial return into pre-market deliberate under-pricing and aftermarket overpricing. Our work contradicts, in part, previous studies in that the initial returns established, during the listing period, can explain not only IPO under-pricing, but also overpricing. In other words, the listing price reflects the private information collected during the process of going public and, partially, public information (stock market behaviour) known at the time of the offer.
\end{abstract}

Keywords: Initial Public Offering (IPO), Initial Return, Under-pricing, Overpricing. 


\section{1l Macrothink}

International Journal of Accounting and Financial Reporting

ISSN 2162-3082

2011, Vol. 1, No. 1

\section{Introduction}

During the last decades, financial economists characterized the context of initial public offerings by a phenomenon of underpricing of the securities: the first trading days. This initial underpricing represents, generally, an abnormal profit for the primary buyers of new issues and can be interpreted as a significant cost for the issuers of these securities. It is characterized by a sale price of the shares which is, generally, lower than the equilibrium price. That is justified by the fact that the share price increases mostly at the beginning of the listing period. This phenomenon is confirmed on an international plan (Ibbotson (1975); Loughran \& Ritter (1995); Certo \& al (2001); Derrien \& Womack (2003); Li \& Naughton [2007); Dufour \& al (2008).

Indeed, a more particular attention is attributed in this underpricing. It remains a main challenge for the academicians although the previous studies advanced many plausible explanations. Nevertheless, IPO underpricing, characterizing the new issues, was questioned by some empirical results, proving the appearance of the phenomenon of the overpricing these last years.

Gao (2010) asserts that the exceptionally raised initial returns and the high participation of individual investors suggest the inflation of market prices. To avoid these difficulties at the level of the empirical study, it is crucial to separate the components of the initial returns in elements of under and overpricing. Indeed, the initial returns present at the same time one deliberated underpricing and an irrational overpricing. Consequently, regressions on the determiners of the underpricing and the overpricing are to be led to know the factors which serve to generate them. For that purpose, we considered interesting to answer the following problem:

Is it advantageous to separate the initial return during the initial public offering, in elements of under and overpricing? And what are the determiners of these elements?

The present article will be subdivided into three parts. The theoretical frame and the hypothesis of our research to be tested, are the object of the first part. The second part treats methodological aspects. The third part presents the analysis and the discussion of the found results.

\section{Context of the study and hypothesis of research}

We are going to examine some hypothesis among which each is represented by very specific measures which are going to serve to define the explanatory factors of the underpricing and the overpricing, given that the separation of the initial returns in components of under and overpricing is very important, according to Gao (2010). We thus begin with the explanations of the hypothesis relative to the initial underpricing. 


\section{Macrothink \\ International Journal of Accounting and Financial Reporting \\ ISSN 2162-3082 \\ 2011, Vol. 1, No. 1}

\subsection{Hypothesis explaining the initial underpricing}

Our hypothesis of research will mainly be focused on the presence of asymmetry of information between the various participants about the stock market. Indeed, our choice is justified by the fact that there is dominance for this informative asymmetry in the explanation of the initial underpricing. So, we have no indicators reflecting the institutional explanations of this phenomenon of underpricing.

\subsubsection{Price of the offer}

The initial price of a new issue indicates the existence of the underpricing although its level seems to have not enough economic importance (Fernando et al (1999)). Companies do not set the prices of the offer in an arbitrary way. In fact, when the objective of the initial public offering is to encourage the participation of individual investors, issuers agree to set a relatively low price to encourage the small potential investors. It will lead, systematically, to an excessive demand of the shares and, consequently, to one important undepricing. Besides, Daly et al (2003) suggest that the highest prices of the offer are associated to a bigger uncertainty as for the future performance of the company. Conversely, the companies which try to attract institutional investors tend to set high prices of the offer. In fact, the institutional investor does not accept cheap shares (Grompers and Metrick (1998)).

The presence of the institutional could cause an increase of the underpricing of the stock-exchange because it needs to be rewarded for the value of the information which it supplies to insure the good marketing of the initial public offering. So during the allowance of the underpriced securities the bank privileges the investors who communicated the best information before the listing (Benveniste and Spindt (1989)). Besides, Jain and Kini (1999) support that the price of a low offer can indicate a low demand, a low value or both at the same time and are, thus, associated to a low short-term performance.

The empirical data gives mitigated results as regards the relation between the price of the offer and the underpricing. Ibbotson and al (1988) notice that the companies which offer very low prices register generally high levels of underpricing. They show that the lowest prices of the offer present higher risks and are the object of transactions of speculation. We, thus, propose the following hypothesis:

\section{H1: The scale of underpricing increases with the decline of the offer price}

\subsubsection{Size of the offer}

The size of the offer is supposed to be in negative correlation with the level of the underpricing. According to Miller and Reilly (1987), Clarkson and Simunic (1994), the size of the offer indicates the uncertainty on the new issues. So, the most known companies, with a big work experience, may more go public. It contributes to reduce the risk perceived on behalf of institutional investors during the initial public offering (Crankcase and al (on 1998), Jain and Kini (2000)). Crankcase and Manaster (1990) assert that, besides the uncertainty which surrounds the initial public offering, investors take into account its size to value the performance of this new issue. Empirically, several studies prove a negative relation between the quantity of the mobilized funds and the level of the underpricing (Chalk and Peavy (1990) 
and Clarkson and Merkley (1994)).

\section{$H$ 2: There is a negative link between the size of the offer and the initial underpricing}

\subsubsection{Amount of capital collected during the offer}

By examining the existence of the initial returns during the first trading day, Uddin (2008) focuses on a comparative study between Singapore and Malaysia by showing that the amount of capital collected during the listing period is negatively and significantly correlated in unintendedunderpricing. Indeed, the companies which benefit from important amounts of capital are characterized by low levels of underpricing. Uddin (2008) asserts that the capital collected during the issue period, is an explanatory factor of the asymmetry of information which characterizes the environment of the initial public offering. So, a low level of this underpricing implies a reduced level of the asymmetry of information and, consequently, the uncertainty on the value of the listed firm is very limited. This company, thus, has more luck to attract the potential investors and, thus, realize a large amount of money. Our hypothesis can be reformulated as follows:

\section{H3: The level of underpricing decreases with the increase of the capital collected during the offer}

\subsubsection{Market capitalization}

The hypothesis of signal stipulates that the initial underpricing is an act deliberated by the company with the aim of indicating its quality to the participants on the market. We are going to consider the market capitalization as being a signal informing about the quality of the company.

The study of Sohail and Raheman [2009] allows to note the importance of the hypothesis of signal advanced by Allen and Faulhaber [1989] and Welch [1989]. Indeed, this study shows that the market capitalization indicates, very effectively, the value of the Financial Company and not financial firms listed on the Stock Exchange. It shows itself by the positive and very significant relationship between the market capitalization and the level of the underpricing of the new issues.

By referring to various intervals of the market capitalization, Bundoo (2007) asserts that the biggest companies are most underpriced. This is in accordance with the hypothesis of signal. Consequently, the market capitalization establishes a good signal of the underpricing. So, in the model of Welch (1989), the good firms try to distinguish themselves from the bad firms by incurring a cost which these last ones cannot support. Our hypothesis is as follows:

\section{$H$ 4: The scale of underpricing increases with the level of market capitalization during the listing period}

\subsubsection{Listing Market}

Uddin (2001) asserts that the listing market affects the underpricing of initial public offerings. Within the framework of our study we propose a dummy variable which is equal to 1 if the company is listed on the Alternext market, 0 otherwise. In fact, our choice is based on the 
number of the new listings on every market, and the Aleternext d' Euronext market presents a number of 55 new listings, which is the most raised, by comparison to the other markets. Our hypothesis is the following one:

H5: There is a relation between the initial underpricing and the stock exchange market chosen by every company

\subsubsection{Size of the firm}

The size of the company is generally negatively associated with its risks. The big companies which have a better access to the capital of investment are more diversified, controlled well and have a better access to the necessary resources for the profitability of the firm and its survival (Finkle (1998)). These factors contribute to reduce the uncertainty around the listing period of the big companies for the potential investors (Kiymaz (2000), Bhabra and Pettway (2003)). However, the inverse relation between the risk and the size of the firm is supported in common by numerous studies (Titman and Wessels (1988); Schultz (1993)).

Empirically, several studies reported a negative link between the size of companies and short-term underpricing (Ibbotson et al (1994); Crankcase et al (1998)). Consequently, the big size of the firm allows to reduce the uncertainty on the value of the firm, the entrainant reduction of the asymmetry of information, and consequently, the decrease of the level of underpricing. Our hypothesis is, thus, the following one:

\section{H6: The scale of underpricing decreases with the increase of the firm size.}

\subsubsection{Age of the firm}

The age of the company is supposed to have an impact on the level of the underpricing after initial public offering. First of all, companies recently created, by opposition to those more former, present a bigger uncertainty ex-ante. It is due to the fact that the least experimented companies may be less followed by the financial analysts because they have enough published historic financial data. Second, the availability of the information about companies operating for several years, contributes to reduce the asymmetry of information during the listing period (Ritter (1991), Hensler and al (1997)). This uncertainty, as for the future prospects of the company, will be translated by an increase of the underpricing (Bilson and al (2003)). Our Hypothesis is as follows:

H7: The age of the firm weakens the level of underpricing during the initial public offering

\subsection{Hypothesis explaining the overpricing}

These hypothesis are going to be based mainly on the behaviour of the stock market during the listing time and by the appearance of the noise traders who represent in turn a no-arbitrage condition, next to the constraints of the short sale, serving to divert the prices of listed share in the increase. 


\section{Macrothink \\ International Journal of Accounting and Financial Reporting \\ ISSN 2162-3082 \\ 2011, Vol. 1, No. 1}

\subsubsection{Rate of the oversubscription}

Recent researches on the behavior of the investors concentrate on individual investors. By using a sample of companies listed on the Stock Exchange during 1999-2001, Derrien (2005) shows that the new issues which are the object of a raised demand on behalf of individual investors have high initial returns followed by lower long-term returns. This reflects an overpricing characterizing these listed companies. Similar conclusions are reported by Cornelli and al (2006) by using data relative ' to the grey market ' of Europe before initial public offering.

Gao (2010) asserts that the current regulations in China stipulate that the underwriter is anxious to attribute $20 \%$ of the shares listed on the Stock Exchange for institutional investors and the $80 \%$ remaining are the object of an offer to individual investors by referring to a system of lottery at the price of offer. Gao (2010) used the logarithm of the ratio of oversubscription to indicate the demand of individual investors for the shares listed on the Stock Exchange. Gao (2010) finds that this ratio is positively correlated in the overpricing, this confirms his predictions and the expected signs. This explains the fact that the high demand of individual investors during the period of listing increases the stock-exchange overpricing. Consequently, it can justify the idea of Derrien (2005) when the favorable behaviour of individual investors during the initial public offering affects positively the overpricing.

The fact that Gao ( 2010 ) asserts that $80 \%$ of the shares offered during the initial public offering are attributed to individual investors and that the demand of these investors makes increase the overpricing, it allows us to conclude that these last ones are evil informed.

Our hypothesis stipulates that:

H8: There is a relationship between the oversubscription rate and the overpricing of new issues

\subsubsection{The volume of transaction}

Measured as a percentage of the total shares in circulation. By using a data of the trade volume, Ofek and Richardson (2003) show that the high initial returns occur when the institutional sell the shares of initial public offerings to individual investors during the first trading day.

Besides, Cornelli et al (2006) find that the total transaction volume of the new issues is positively correlated with individual measures of investor behaviour, on the European markets, this leads to the appearance of the high prices, the first trading day, and low long-term returns. In other words, the small investors are ready to pay a price which exceeds so much the fundamental value, when they are overoptimistic.

\section{H 9: The volume of transaction, the first trading day, increases the scale of overpricing}




\section{MlMacrothink}

International Journal of Accounting and Financial Reporting

ISSN 2162-3082

2011, Vol. 1, No. 1

\subsubsection{Momentum Effect}

It is well mentioned well by Loughran and Ritter (2002) that the returns on stock markets, before the initial public offering, have a positive impact on the initial returns during the initial public offering. However, the reason of this positive impact is not very clear. The classic information theory involves that the public information as the dynamism of the market (market momentum) should not affect underpricing. The underwriter has to adjust the price of the offer to eliminate the impact of any public information. Consequently, the behavioural arguments are developed.

Loughran and Ritter ( 2002 ) uses the prospects theory to explain that the underwriters adjust, partially, the price of the offer for the public information about the momentum of the market and the new issues, in high dynamism, are characterized by one important underpricing. Miller (1977) shows that the prices of the shares can deviate from their intrinsic values further to on optimism of the investors.

The dynamism of the market, considered as an indicator of the behaviour of the investor, can cause the overpricing after initial public offering. As mentioned previously, testing empirically these two contradictory arguments depends, in a crucial way, on the separation between the components of the underpricing and the overpricing in a given initial return.

Generally, the market momentum represents the return on the market during a period of a month before the date of the initial public offering (Gao (on 2010)). We used this test to know if the general behaviour of the market leads to an overpricing after the initial public offering. We, thus, propose the following hypothesis:

\section{H10: The overpricing is an increasing function of the momentum effect}

\section{Methodology}

\subsection{Sampling and Data Collection}

\subsubsection{Sampling}

Our study concerns a sample of 143 French companies listed on the Stock Exchange, between 2006-2010. This sample was obtained from the site of Euronext (www.euronext.com). We removed certain observations of our sample as far as the logic of transfer of markets or the private placement does not correspond to that of the first initial public offering. So, we note that the number of new issues during 2006-2007 is relatively important. This involves the existence of a relatively favorable stock-exchange context.

Companies included within our sample, result from different business sectors, the following ones of which the most represented are:

-The participation and real-estate development (15 observations)

-Internet ( 9 observations)

-Biotechnology (11 observations)

Most of the companies of our sample were introduced on the free market and 
Alternext d' Euronext. Indeed, we can distribute our sample as follows:

Table 1. Sample Selection Procedure

\begin{tabular}{|l|l|}
\hline Market & Number of Company \\
\hline Eurolist & 38 \\
\hline Alternext & 55 \\
\hline Marché Libre & 50 \\
\hline Total & $\mathbf{1 4 3}$ \\
\hline
\end{tabular}

Figure 1. Companies Number Evolution between 2006-2010

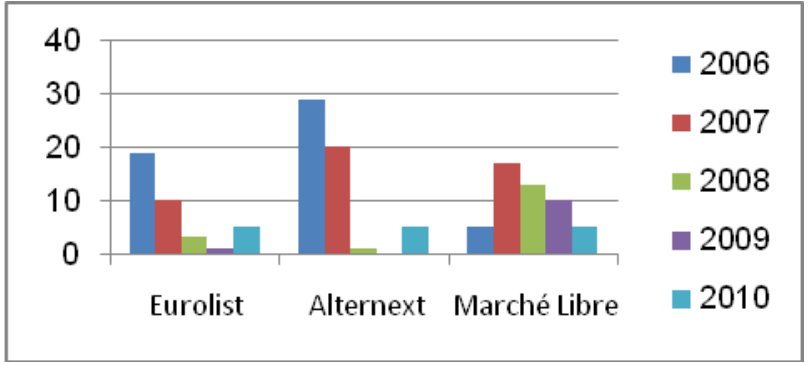

We collected data from the site of Euronext and the prospectus of new issues. Several companies were eliminated from the sample given that it is not about the first initial public offering. Indeed, 47 companies were removed, among which 33 that made a transfer from a market to the other one and 14 companies which got by a private placement and not by a public offer.

\subsubsection{Data Collection}

We tried to obtain all the stock-exchange data with the site of Euronext. So, we turned to the prospectus of initial public offering to determine certain accounting and other general data about the company. These leaflets shall be deposited with the Authority of Financial Markets and can be consulted with the site of every listed company. 


\section{IN Macrothink

\subsection{Definition and measures of variables}

\subsubsection{Model}

We examine the following multivariate regression:

- Initial Return ${ }_{i, t}=a+$ b. $\quad$ L.D $_{i, t}+$ c. $\quad$ C.C $C_{i, t}+$ d. $\quad$ O.S $S_{i, t}+$ e. $\quad$ O.P $P_{i, t}+$ f. $\quad$ CAP $_{i, t}$ + g. $M_{1, t}+$ h. O.R ${ }_{i, t}+$ i. T. $V_{i, t}+$ j. F. $A_{i, t}+$ k. F.S $S_{i, t}+1 . D \cdot V_{i, t}+\varepsilon_{1}, i, t$

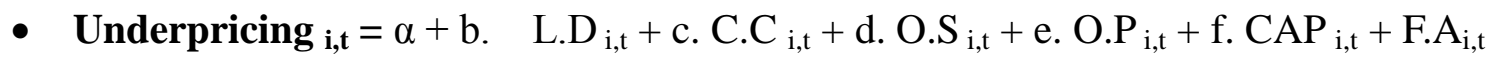
+ h. F.S $S_{i, t}+$ i. D. $V_{i, t}+\varepsilon_{2}, i, t$

- Overpricing $i, t=\beta+$ b. M.E ${ }_{i, t}+$ c. O.R ${ }_{i, t}+$ d. T. $V_{i, t}+$ e. F. $A_{i, t}+$ f. F. $S_{i, t}+$ g D.V $V_{i, t}$ $+\varepsilon_{3}, \mathrm{i}, \mathrm{t}$

Where :

$\checkmark$ L.D : Listing Delay

$\checkmark$ C.C : Capital Collected

$\checkmark$ CAP : Capitalization

$\checkmark$ O.S : Offer Size

$\checkmark$ O.P : Offer Price

$\checkmark$ M.E : Momentum Effect

$\checkmark$ O.R : Oversubscription Ratio

$\checkmark$ T.V : Transaction Volume

$\checkmark$ F.A : Firme Age

$\checkmark$ F.S : Firme Size

$\checkmark$ D.V : Dummy Variable 


\section{Macrothink \\ International Journal of Accounting and Financial Reporting \\ ISSN 2162-3082 2011, Vol. 1, No. 1}

\subsubsection{Variables Definition}

By referring to us in the previous studies (for example those of Lee et al. (1996a, 1996b), (Uddin (2008)), Bundoo (2007), Boudriga et al (2009), Chowdhry Sherman (1996)), we have chosen and retained a set of stock-exchange indicators, which are going to serve to define the phenomenon associated to an operation of initial public offering and the factors which can affect them. Indeed, the underpricing and the overpricing are two phenomena which can accompany the new issues and their importance at the level of the initial return is different from one company to another one.

The measures adopted to study the initial returns during the period of listing are indicated in table 2 . 
Table 2. Variables used

\begin{tabular}{|c|c|}
\hline \multicolumn{1}{|c|}{ Variables } & Definitions \\
\hline $\begin{array}{c}\text { Listing Delay } \\
\text { (L.D) }\end{array}$ & $\begin{array}{c}\text { The number of days separating the closing of subscriptions and the day of the } \\
\text { IPO (Uddin (2008), Loughran et al(1994), Chowdhry (1996), Chan et al. } \\
\text { (2004). }\end{array}$ \\
\hline $\begin{array}{c}\text { Capital Collected } \\
\text { (C.C) }\end{array}$ & $\begin{array}{c}\text { Logarithm of the amountof capital raised during the listing period (Beatty } \\
\text { andRitter(1986),ClarksonandMerkley(1994),Leet al.(1996aand1996b) } \\
\text { (Uddin (2008)) }\end{array}$ \\
\hline $\begin{array}{c}\text { Capitalization } \\
\text { (CAP) }\end{array}$ & Logarithm of the capitalization (Bundoo (2007)) \\
\hline $\begin{array}{c}\text { Offer Price (O.P) } \\
\text { Offer Size (O.Z) }\end{array}$ & $\begin{array}{c}\text { logarithm of the number of offered shares * offer price (Boudriga et al } \\
\text { (2009)) }\end{array}$ \\
\hline $\begin{array}{c}\text { Firm Size (F.S) } \\
\text { logarithm of total assets at the end of the year preceding the IPO of the } \\
\text { issuing firm (Boudriga et al (2009)) }\end{array}$ \\
\hline $\begin{array}{c}\text { Firm Age (F.A) } \\
\text { Dummy Variable } \\
\text { (D.V) }\end{array}$ & \begin{tabular}{c} 
logarithm of the number of years between the year of creation and the IPO \\
Dumm variable taking one if the company is listed on Alternext, 0 \\
\hline
\end{tabular}
\end{tabular}

Explanatory Variables of the Overpricing

\begin{tabular}{|c|c|}
\hline $\begin{array}{c}\text { Momentum Effect } \\
\text { (M.E) }\end{array}$ & Return ofmarket indexone monthprior theIPO ((GAO (2010)) \\
\hline Transaction & The percentageof totalshares outstanding (Gao (2010)) \\
Volume (T.V) & Logarithm (Number of sharesrequested/ numberof shares offered) (Gao \\
\hline $\begin{array}{c}\text { Oversubscription } \\
\text { Ratio (O.R) }\end{array}$ & $(2010))$ \\
\hline
\end{tabular}

Variables of Control

\begin{tabular}{|c|c|}
\hline Firm Size (F.S) & $\begin{array}{c}\text { logarithm of total assets at the end of the year preceding the IPO of the } \\
\text { issuing firm (Boudriga et al (2009)) }\end{array}$ \\
\hline Firm Age (F.A) & logarithm of the number of years between the year of creation and the IPO \\
\hline $\begin{array}{c}\text { Dummy Variable } \\
\text { (D.V) }\end{array}$ & $\begin{array}{c}\text { Dummy variable taking one if the company is listed on Alternext, } 0 \\
\text { otherwise. }\end{array}$ \\
\hline
\end{tabular}

\section{Description and analysis of the results}

\subsection{Determination of the intrinsic value}

We obtained IPO underpricing by turning to the application of the difference between the price of the offer and the intrinsic value of the new issues. It is from the study of Gao (2010) that we brought to light this definition of this underpricing. This definition is different from those mentioned in the other studies. Indeed, most of the previous studies ended in results 


\section{Macrothink}

International Journal of Accounting and Financial Reporting

ISSN 2162-3082

according to which the underpricing also represents the initial return. Nevertheless, the study of Gao (2010) comes to contradict all these studies by showing that the initial return includes components of IPO under/overpricing.

According to Gao (2010), we thus have:

(Offer Price - Market Price)

Initial Return $=$

Market Price

(Offer Price - Intrinsic Value)

Underpricing $=$

Intrinsic Value

\section{(Market Price - Intrinsic Value)}

\section{Overpricing $=$}

Intrinsic Value

The separation between the underpricing and the overpricing is difficult on the developed markets where the initial returns are low (Gao (2010)).

To calculate the intrinsic value, we opted for a method different from that of Gao (2010). Indeed, these last ones referred to a methodology identical to that of Purnandam and Swaminathan (2004), based on the use of the rate of price / profits. However, several initial public offerings had no positive profits, what limited the size of their sample. For that reason, these authors replaced profits by sales and used the rate of price / sales (P/S), because sales are generally available. These authors, also, used the rate Price / EBITDA (P / EBITDA), because EBITDA measures the cash operational flow, and it is less subjected to the accounting manipulations. 
Table 3. Determination of the intrinsic value

\begin{tabular}{|l|l|l|l|l|}
\hline \multicolumn{1}{|l|}{$\mathbf{I}_{\mathrm{i}, \mathrm{t}}=\boldsymbol{\alpha}+\boldsymbol{\beta} \mathbf{M R}_{\mathrm{i}, \mathrm{t}}+\boldsymbol{\varepsilon}_{\mathrm{i}, \mathrm{t}}$} \\
\hline Variable & Coefficient & S.Dev & t-Student & Prob. \\
\hline $\boldsymbol{\alpha}$ & 10.62966 & 1.483031 & 7.17 & 0.000 \\
\hline $\boldsymbol{\beta}$ & 1.507428 & 0.6540648 & 2.30 & 0.023 \\
\hline $\mathbf{R}^{\mathbf{2}}$ & 0.0363 & & \\
\hline Adjusted $\quad \mathbf{R}^{\mathbf{2}}$ & 0.0295 & & \\
\hline F-statistic & 5.31 & \multicolumn{4}{|l}{} \\
\hline Prob(F-statistic) & 0.0226 & & \\
\hline
\end{tabular}

Concerning our study, the intrinsic value is obtained by a linear regression while considering the market price and the listing price, of all the new issues, between 2006-2010. Replacing $\alpha$ and $\beta$ by their value in the equation of the model according to the market price observed the first day of lisitng, the shares listed on the Stock Exchange of Paris, we succeeded to determine the intrinsic value of every listed share.

The model, thus, spells as follows:

$\mathrm{IV}_{\mathrm{i}, \mathrm{t}}=\alpha+\boldsymbol{\beta} \mathrm{MR}_{\mathrm{i}, \mathrm{t}}+\varepsilon_{\mathrm{i}, \mathrm{t}}$

It stands out from the table 3 , that the coefficients $\alpha$ and $\beta$, are statistically significant ( $\alpha$ is significant at the level of $1 \%$ and $B$ at the level of $5 \%$ ).

\subsection{Multivariate analysis}

\subsubsection{Analysis of the initial return}

By opting for a transversal analysis, the observation of table 4 shows that the initial return is affected negatively and significantly by the momentum effect (indicator of the overpricing), the market capitalization (indicator of the underpricing) and positively and significantly by the delay of subscription (indicator of the underpricing). The separation of the initial return is confirmed, then, within the framework of our study. It can justify the fact that the offer price reflects the private information collected during the process of the listing period and partially the public information (behaviour of the stock market) known at the time of the offer. Consequently, the new issues are overpriced on the average but present, generally, a positive 
initial return.

More exactly, the fact than the initial return is positive, that does not mean that it is only influenced by the indicators of the underpricing. Indeed, this initial return includes the components of the overpricing, which represent public information about the behaviour of the noise traders, or about the no-arbitrage condition, which have an essential role in the explanation of the initial return. In our study, we observed that when the behaviour of the market (momentum Effect) decline, the initial return improves in a significant way. It means that this public information which informs us about the behaviour of the market, as an indicator of IPO overpricing, plays its full role in the explanation of the evolution of the initial return.

Given that, the behaviour of the market can include the behaviour of the noise traders, our results are close, thus, to those found by Derrien (2005) in the sense where the profitability offered to institutional investors is not paid by the issuer, but by the noise trader who is ready to pay a high price for the shares listed on the Stock Exchange. It still means that the conditions of the market have an impact on the market price of the shares which is partially integrated into the price of the offer. So, the underpricing is a price paid to extract only the private information, seen that the classic information theory implies that the public information should not affect the initial return during le listing period. It justifies, still, the necessity of separation of the initial return in components of the under/overpricing. The public information reflects the conditions of market and, more exactly, the momentum effect.

If the favorable conditions of the market, which prevail at the time of listing, generate an excess of optimism of certain investors on the perspectives of the company listed on the Stock Exchange, then the first condition of the result of Miller (1977), according to whom the conditions of the market have an impact on the equilibrium price of the shares of the new issues, will be performed. Consequently, next to the theories proposed by Benveniste and Spindt ( 1989 ) and Chowdhry and Sherman ( 1996 ) and the others, in which only the private information has an impact on the price of the offer, the conditions of the market at the listing time establish explanatory factors of the initial return. These conditions represent, in fact, the demand of the individual investors which depends essentially on orders of the market and on the public information and which does not contain private information. This demand establishes then a major determinant of the prices of the new issues. It is necessary, thus, following the example of Gao (2010), to separate the initial return in components of under/overpricing, to understand better the factors which serve to generate them.

\subsubsection{Analysis of IPO underpricing}

The results of the regression, presented in table 4 show that the market capitalization, the size of the offer, the price of the offer, the delay of subscription, the size of the firm and the dummy variable have a statistically significant effect on IPO underpricing. The raised capital of the issue as well as the age of the firm does not seem to have an impact on the level of the underpricing. The positive sign of the delay of subscription is compatible with the works of Chowdhry and Sherman (1996), on the market of United Kingdom, the works of Megginson 
and Tian (2007), on the Chinese market, and those of Boudriga and al (2009), on the Tunisian market.

It can be explained by this idea that the underpricing is more likely to be involuntary, given that the delays of announcement lead to an increase of the flights of information about the real value of the offered share. Indeed, the rationed investors, who are in search of the short-term profits, try to catch by pushing those who intervene on the market, to buy the shares of the listed company, during the period of exchange after listing. So, it is difficult to believe that the company is voluntarily underpriced, when the delay of announcement lengthens. This explains the increasing function between the underpricing and the delay of subscription.

Our results show a positive relationship between the price of the offer and the underpricing. It can be attributed to a low demand for the listed shares for rather high prices or for an increase of the uncertainty which surrounds the new issue with rather high prices.

The size of the offer is correlated positively with the underpricing, because this variable indicates the uncertainty about listed companies (Miller and Reilly (on 1987), underpricing is, then, an increasing function of this uncertainty and, consequently, the asymmetry of information. The increase of the size of the offer pulls one important underpricing. It still means that the stock-exchange environment of the listed French companies between 2006-2010, is characterized by a big asymmetry of information.

The market capitalization, as being an indicator of the signal, affects negatively the underpricing. This is contradictory to the results of Bundoo (2007). Indeed, the negative relationship between the market capitalization and IPO underpricing can be explained by the idea according to which companies with high capitalization that are, generally, companies with high quality do not want to underprice their listed shares for the fear of the dispersal of their structure of ownership. What does not incite them to excess underpriced securities, not to attract the small investors. The size of the listed firms is negatively correlated with the underpricing. This explains that the big companies which are characterized by an uncertainty reduced around the listing time and, consequently, a reduced level of the asymmetry of information, do not underprice their shares during the period of listing. Our results are in accordance with those found by Ibbotson et al (1994), Crankcase et al (1998)).

Finally, the Alternext market affects negatively and significantly the underpricing. It confirms that the market of Stock Exchange can influence IPO underpricing of the new issues (Uddin (2001)). Indeed, our results assert that the companies listed on Alternext don't underprice their listed shares, because of the existence of a listing sponsor who accompanies them during the process of listing and during all the stock-exchange life. Given that this listing sponsor plays the determining role in the control of the respect for the obligations of clarity or transparency to which the company is subjected, the level of asymmetry of information is reduced affecting negatively the underpricing.

Indeed, a low level of uncertainty and asymmetry of information, about the value of the company weakens the level of the underpricing. The listing on the market of Alternext requires the transparency and the brightness of the company situation, leading to a reduced 


\section{Al Macrothink}

International Journal of Accounting and Financial Reporting

ISSN 2162-3082 2011, Vol. 1, No. 1

level of the underpricing. Consequently, there is a negative relationship between the Alte rnext market and IPO underpricing.

\subsubsection{Analysis of IPO overpricing}

In fact, we observed, from table 4, that three explanatory variables of IPO overpricing: the ratio of oversubscription, the volume of transaction and the momentum effect, are significant.

The observation of our results, shows the existence of the results not corresponding to those mentioned by Cornelli et al (2006) and Gao (2010). Indeed, we found that the volume of transaction and the momentum effect are correlated negatively with the overpricing.

The momentum effect allows to know the behaviour of the stock market. Cornelli and Goldreich (2001) assert that the analysts propose, generally, a price which depends on the average price of the market. They have, thus, tendency to overprice companies at the time of their listing (Houge et al). Indeed, the negative relationship between the momentum effect and the overpricing can be explained by the fact that the prices proposed by the issuers are low in the average price of the market. This weakens the risk of the overpricing during the initial public offering. So, the presence of an asymmetry of information is well illustrated here, that from the value of a share at the time of the listing does not reflect, systematically, its real intrinsic value. The rate of oversubscription is positively correlated in the level of IPO overpricing. Miller (1977) asserts that the markets of initial public offerings are characterized by constraint of the short sale. Indeed, the stock-exchange overpricing can, thus, be attributed to the incapacity of the arbitragers to sell short, considering the high demand of the listed securities.

Consequently, the short sale constraint, before listing, represents the no-arbitrage condition which can cause a deviation in the rise in prices during the initial public offering and the overpricing well appears further to such an obstacle. This positive relationship confirms the result of Gao (2010), in the sense that the rate of answer of the investors affects positively the overpricing. 
Table 4. Factors explaining the initial return and the components of initial returns

\begin{tabular}{|c|c|c|c|}
\hline & Initial return & Underpricing & Overpricing \\
\hline Capitalization & $\begin{array}{c}-2.4276 * * \\
(-2.31) \\
\end{array}$ & $\begin{array}{c}-0.572 * * * \\
(-3.64) \\
\end{array}$ & - \\
\hline Offer Price & $\begin{array}{c}17.426 * * * * \\
(11.20) \\
\end{array}$ & $\begin{array}{c}3.0615 * * * \\
(11.63) \\
\end{array}$ & - \\
\hline Capital Collected & - & $\begin{array}{c}-0.297 \\
(-1.63) \\
\end{array}$ & - \\
\hline Offer Size & $\begin{array}{r}0.9577 \\
(0.98) \\
\end{array}$ & $\begin{array}{c}0.2676 * \\
(1.72) \\
\end{array}$ & - \\
\hline Listing Delay & $\begin{array}{c}0.2106 * * * \\
(2.39) \\
\end{array}$ & $\begin{array}{c}0.0406 * * * \\
(2.74) \\
\end{array}$ & - \\
\hline Transaction Volume & - & - & $\begin{array}{c}-\mathbf{0 ,}, 84008 * * * \\
(-9.95)\end{array}$ \\
\hline Oversubscription Ratio & - & - & $\begin{array}{l}0.1299 * * \\
(2.00)- \\
\end{array}$ \\
\hline Momentum Effect & $\begin{array}{c}-1.7323 * * * \\
(-3.88) \\
\end{array}$ & - & $\begin{array}{c}-0.13218 * * * \\
(-4.45)\end{array}$ \\
\hline Firm Size & - & $\begin{array}{c}-0.1206 * * * \\
(1.72) \\
\end{array}$ & - \\
\hline Firm Age & $\begin{array}{l}1.2114 \\
(1.32) \\
\end{array}$ & $\begin{array}{l}0.1354 \\
(0.90) \\
\end{array}$ & - \\
\hline dummy Variable & $\begin{array}{l}1.4317 \\
(1.62) \\
\end{array}$ & $\begin{array}{c}-0.4455 * * * \\
(-2.79) \\
\end{array}$ & - \\
\hline $\mathbf{N}$ & 90 & 82 & 136 \\
\hline $\mathbf{R}^{2}$ & 88.80 & 70.08 & 74,18 \\
\hline F value & $\begin{array}{l}94.0006 \\
(0.0000)\end{array}$ & $\begin{array}{l}21.6709 \\
(0.0000)\end{array}$ & $\begin{array}{c}127.3669 \\
(0.0000)\end{array}$ \\
\hline
\end{tabular}

\section{Conclusion}

This study allowed us to show that the initial return consists of elements of under/ overpricing. It is crucial, thus, to separate the initial return in components of under and overpricing to understand better the factors which can influence them during the period of listing. Our study comes to contradict, partially, the previous studies in the sense that the initial return observed during the listing period is not only reflected IPO underpricing. Indeed, the new issues are overpriced on average but present a positive initial return. More exactly, the price of the offer reflects the private information collected during the process of listing and partially the public information (behaviour of the stock market) known at the time of the offer.

Our results reveal a positive impact, of the offer price and the listing delay, on the underpricing. However, we note a negative and significant relationship between the market 
capitalization, the size of the firm, the dummy variable and the underpricing. The positive and significant correlation between the listing delay and the underpricing shows that this last one is more likely to be involuntary given that the delays of announcement lead to an increase of the flights of information on the real value of the offered share. In other words, the company is involuntarily underpriced when the delay of announcement stretches out. The positive and significant relationship (at the level of $1 \%$ ) between the price of the offer and the underpricing can be attributed to a demand decreased for the issues at prices brought up or to an increase of the uncertainty which surrounds the new issues with high prices.

So, the stock-exchange environment of the French companies which opened their capital to the public between 2006-2010 is characterized by a big informative asymmetry given the positive relationship between the size of the offer and IPO underpricing. Contrary to Bundoo (2007), the market capitalization, as signal on the quality of the listed firm, is correlated negatively with the underpricing.

The market of Alternext influences negatively the level of underpricing. It can be due to the existence of a listing sponsor who accompanies the company during the process of listing and who checks the respect for the obligations of clarity for transparency to which is subjected the company. This reduces the asymmetry of information and, consequently, IPO underpricing.

So, our multivariated analysis highlights a negative and significant association (at the level of $1 \%$ ) between the momentum effect, the volume of transaction and the overpricing. These results are not corresponding to those mentioned by Cornelli et al (2006) and Gao (2010). Nevertheless, the positive relationship between the ratio of oversubscription and IPO overpricing is in accordance to that proved by Gao (2010). It can be explained by the fact that the constraint of the short sale before listing represents a limit to the arbitration which can lead to a deviation in the rise in prices, during the listing period and the overpricing as well appears further to such an obstacle.

\section{References}

[1] Agarwal, S., C. Liu and S.G. Rhee (2008), 'Investor demand for IPO's and aftermarket performance: Evidence from the Hong Kong stock market', Journal of International Financial Markets, Institutions and Money, 18 (2): 176-19

[2] Allen, F., \& Faulhaber, G., (1989), "Signalling by underpricing in the IPO market", Journal of financial Economics 23, 303-323.

[3] Benveniste, L., \& Spindt, P., (1989), « How Investment Bankers Determine the Offer Price and Allocation of New Issues », Journal of Financial Economics, Vol. 24,pp. 343-361.

[4] Bhabra, H. S. and R. H. Pettway (2003), 'IPO prospectus information and subsequent performance', Financial Review, (38): 369-397.

[5] Bilson, C., R. Heanry, J. G. Powell and J. Shi (2003), 'The Decision to Voluntary ProvideAn IPO Prospectus Earnings Forecast: Theoretical Implication and Empirical Evidence' Working paper, Australian National University 
[6] Booth, James R and Lena Chua, (1996). «Ownership, Dispersion, Costly Information and IPO Underpricing», Journal of Financial Economics 41: 291-310.

[7] Boudriga et al (2009), "What determines IPO underpricing? Evidence from a frontier market”, MPRA Paper No. 18069, posted 22. October 2009 / 01:09

[8] Bundoo, S.K., (2007), «An Analysis of IPOs Underpricing in Mauritius», African Journal of Accounting, Economics, Finance and Banking Research, Vol.1.No.1. 2007.

[9] Carter R., F. Dark and A. Singh (1998), 'Underwriter reputation, initial returns, and the long- run performance of IPO stocks', The Journal of Finance, 53: 285-311.

[10] Carter R. and S. Manaster (1990), 'Initial public offerings and underwriter reputation', Journal of Finance, 45: 1045-1068.

[11] Chalk A.J. and J.W. Peavy (1987), 'Initial Public Offerings: Daily Returns, Offering Types and the Price Effect', Financial Analysts Journal, 43: 65-69.

[12] Chan K.L., K.J. Wei and J.B. Wang (2004), 'Underpricing and long-term performance of IPO's in China', Journal of Corporate Finance, 10: 409-430.

[13] Chang X., A.F. Gygax, E. Oon and H.F. Zhang (2008), 'Audit quality, auditor compensation and initial public offering underpricing', Accounting and Finance, 48 (3): 391 416

[14] Clarkson, P. M., and D. Simunic (1994), 'The association between audit quality, retained ownership, and firm-specific risk in U.S. and Canadian IPO markets', Journal of Accounting and Economics, 17: 207-228.

[15] Clarkson, P. M. and J. Merkley (1994), 'Ex Ante Uncertainty and the Underpricing of

Initial Public Offerings: Further Canadian Evidence', Canadian Journal of Administrative Sciences, II(1): 54-67

[16] Chowdhry, B. and A. Sherman (1996), 'The winner's curse and international methods of allocating initial public earnings', Pacific-Basin Finance Journal, 4: 15-30.

[17] Certo et al (2001), "Signalling firm value through board structure: An investigation of Initial Public Offerings", ENTREPRENEURSHIP; THEORY and PRACTICE.

[18] Cornelli, F., \& Goldreich, D. (2001), « Bookbuilding and Strategic Allocation », Journal of Finance vol 56, pp. 2337-2369.

[19] Cornelli, F., \& Goldreich, D. \& Ljungqvist, A., (2006) "Investor Sentiment and Pre-IPO Markets." Journal of Finance, 61 (2006), 1187-1216.

[20] Daily, C.M., S.T. Certo, D.R. Dalton, and R. Roengpitya (2003), 'IPO underpricing: a meta-analysis and research synthesis', Entrepreneurship: Theory and Practice, 27 (3) : $271-295$ 
[21] Derrien, F. (2005), “IPO Pricing in 'Hot' Market Conditions: Who Leaves Money on the Table?" Journal of Finance, 60 (2005), 487-521.

[22] Dufour, Molay \& Olivero, (2008), “ Sous évaluation à l'introduction en bourse et gestion del'actionnariat : l'exemple d'Alternext" ; Working Paper.

[23] Fernando, C., S. Krishnamurthy and P. A. Spindt (1999), 'Offer Price, Target Ownership Structure and IPO Performance', Working paper.

[24] Finkle, T.A. (1998), 'The relationship between boards of directors and initial public offerings in the biotechnology industry', Entrepreneurship Theory and Practice, 22: 5-29.

[25] Gao, Y., (2010), «What Comprises IPO Initial Returns: Evidence from the Chinese Market »,17th Conference on the Theories and Practices of Securities and Financial Markets,2009. Available at SSRN: http://ssrn.com/abstract=1596526.

[26] Gana M.R. and A. EL Ammari (2008), 'Initial Underpricing and Transfer of Shares on the Tunisian Stock Exchange', Journal of Corporate Ownership and Control, 5 (3): 434-444.

[27] Gompers, P. and A. Metrick (1998), 'How are large institutions different from other investors? Why do these differences matter?', Working paper, Harvard BusinessSchool.

[28] Grinblatt, M., \& Hwang, C., (1989), « Signalling and the Pricing of New Issues», The Journal of Finance, Vol. 44, pp. 393-420.

[29] Hensler, D. A., R. C. Rutherford and T. M. Springer (1997) 'The survival of initial public offerings in the aftermarket', Journal of Financial Research, 20: 93-110.

[30 ] Houge, T, Loughran, T, Suchanek, G \& Yan, X, (2001): "Divergence of opinion uncertainly and the quality of initial public offerings", Financial management, $\mathrm{N}^{\circ} 30$.

[31] Ibbotson, R., (1975), « Price performance of commun stock new issues », Journal of Financial Economics, Vol. 2, pp. 235-272.

[32] Ibbotson, R.G., Sindelar, J.L., \& Ritter, J.R. (1988). Initial public offerings. Journal of Applied Corporate Finance, 1, 37-45.

[33] Ibbotson, R. G., J. Sindelar, and J. Ritter (1994), 'The market's problems with the pricing of initial public offerings', Journal of Applied Corporate Finance, 7: 66-74.

[34] Jain, B.A. and O. Kini (1999), 'The life cycle of initial public offering firms', Journal of Business Finance and Accounting, 26: 1281-1307.

[35] Jain, B. A. and O. Kini (2000), 'Does the presence of venture capitalists improve the survival profile of IPO firms?' Journal of Business Finance and Accounting, 27: 1139-1176.

[36] Kiymaz, H.,(2000), The initial and aftermarket performance of IPOs in an emerging market: Evidence from Stock Exchange, Journal of Multinational Financial Management, 2000, vol. 10, pp. 213-227. 


\section{MInstitute Macrothink $_{\text {Int }}$}

International Journal of Accounting and Financial Reporting ISSN 2162-3082

[37] Keloharju, M., (1993), «The winner's curse, legal liability, and the long-run price performance of initial public offerings in the Finland», Journal of Financial Economics, Vol. 34, pp. 251-277.

[38] Kooli, M., and J. Suret (2004). The aftermarket performance of initial public offerings in Canada. Journal of Multinational Financial Management, 14, 47-66.

[39] Lee, P., Taylor, S., \& Walter, T., (1996), «Australian IPO underpricing in the short and long run », Journal of Banking and Finance, Vol. 20, pp. 1189-1210.

[40] Leland, H., \& Pyle, D., (1977), "Informational asymmetries, financial structure, and financial intermediation ", Journal of Finance, $\operatorname{Vol} \mathrm{n}^{\circ} 4$, septembre.

[41] Li \& Naughton, (2007), "Going public with good governance: Evidence from China", Corporate Governance, Journal compilation, Blackwell Publishing Ltd. 2007,Volume 15 Number 6 November 2007.

[42] Liu, J., Nissim. D., \& Thomas, J., (2002), «Equity valuation using Multiples”, Journal of Accounting Research, 40, 135-172.

[43] Liu, J., and F. A. Longstaff, 2004, "Losing Money on Arbitrage: Optimal Dynamic Portfolio Choice in Markets with Arbitrage Opportunities," Review of Financial Studies, 17, 611-641.

[44] Ljungqvist, A. P.; V. Nanda; and R. Singh, (2006), "Hot Markets, Investor Sentiment, and IPO Pricing." Journal of Business, 79 (2006), 1667-1702.

[45] Loughran, T., \& Ritter, J., (1995), « The New Issues Puzzle», The Journal of Finance, Vol. 50, pp. 23- 52 .

[46] Loughran, T., \& Ritter, J., \& Rydqvist, K., (2002), "Initial public offerings: international insights. Pacific-Basin Finance Journal 2, 165-199

[47] McGuinness, P., 1992, An examination of the underpricing of initial public offerings in Hong Kong: 1980-90, Journal of Business Finance and Accounting 19, 165-186.

[48] Megginson, W., \& Tian, L., (2007), « Regulatory Underpricing: Determinants of Chinese Extreme IPO Returns Egulatory », SSRN Paper.

[49] Michaelly, R., \& Shaw, W., (1994), « The pricing of initial public afferings, Tests of adverse selection and signaling theorie », The Review of Financial Studies, Vol.2, pp. 279-319.

[50] Miller, Edward M., 1977, Risk, Uncertainty, and Divergence of Opinion, Journal of Finance 32, 1151-1168.

[51] Miller, R. E. and F. Reilly (1987), 'An examination of mispricing, returns, and uncertainty for initial public offerings', Financial Management, 16: 33-38.

[52] Ofek, E., Richardson, M., (2003). Dot-com mania: the rise and fall of Internet stock pric 


\section{Macrothink \\ International Journal of Accounting and Financial Reporting \\ ISSN 2162-3082 2011, Vol. 1, No. 1}

es. Journal of Finance 58, $1113-1138$.

[53] Purnanandam, A. K., and B. Swaminathan, (2004), “Are IPOs Really Underpriced?" Review of Financial Studies, 17 (2004), 811-848.

[54] Ritter, J. R., (1991), “The Long-Run Performance of Initial Public Offerings”, Journal of Finance 46, 3-27. .

[55] Rock, K., (1986), "Why new issues are underpriced", Journal of Financial Economics, Vol. 15, pp. 187-212.

[56] Schultz, P. (1993), 'Unit initial public offerings', Journal of Financial Economics, 34: 199- 229.

[57] Sohail, M., \& Raheman. A., (2009): «Determinants of Under-Pricing of IPOs Regarding Financial \& Non-Financial Firms in Pakistan», European Journal of Economics , Finance and Administrative Sciences, ISSN 1450-2887 Issue 15 (2009).

[58] Titman, S., \& Trueman, B., (1986), "Information Quality and the Valuation of New Issues," Journal of Accounting and Economics 8:159-172

[59] Titman, S. and R. Wessels (1988), 'The determinants of capital structure choice', Journal of Finance, (43): 1-19.

[60] Uddin, M.H., (2001), "An Investigation on Initial Public Offers in Malaysia," a PhD thesis,National University of Singapore

[61] Uddin, H., (2008), “An Empirical Examination of Intended and Unintended IPO Underpricing in Singapore and Malaysia"; International Research Journal of Finance and Economics ISSN 1450-2887 Issue 20 (2008).

[62] Welch, I., (1989), «Seasoned Offerings, Imitation Costs, and the Underpricing of Initial Public Offerings», The Journal of Finance, Vol. 44, pp.421-449. 